\title{
Research on Innovative Business Plan. Smart Cattle Farming Using Artificial Intelligent Robotic Process Automation
}

\author{
Diana Elena Micle ${ }^{1}$, Florina Deiac ${ }^{1, *}$, Alexandru Olar ${ }^{1}{ }^{(0)}$, Raul Florentin Drența ${ }^{2}$, Cristian Florean ${ }^{3}$, \\ Ionuț Grigore Coman ${ }^{4}$ and Felix Horațiu Arion ${ }^{1,5}$ (D) \\ 1 Department of Economic Sciences, University of Agricultural Sciences and Veterinary Medicine of \\ Cluj-Napoca, 3-5 Manastur Street, 400372 Cluj-Napoca, Romania; diana.micle@usamvcluj.ro (D.E.M.); \\ alexandru.olar@usamvcluj.ro (A.O.); felixarion@usamvcluj.ro (F.H.A.) \\ 2 Faculty of Engineering, North University Center of Baia Mare, Technical University of Cluj-Napoca, \\ 400114 Cluj-Napoca, Romania; drenta.raul@gmail.com \\ 3 Centric IT, 407042 Sannicoară, Romania; cristian.florean@centricit.ro \\ 4 Department of Industrial Engineering, Faculty of Machine Building, Technical University of Cluj-Napoca, \\ 400114 Cluj-Napoca, Romania; ionutcoman.proiecte@gmail.com \\ 5 Asociatia Clusterul Agro-Food-Ind Napoca (AgroTransilvania Cluster), 407039 Dezmir, Romania \\ * Correspondence: florina.deiac@usamvcluj.ro
}

check for updates

Citation: Micle, D.E.; Deiac, F.; Olar, A.; Drența, R.F.; Florean, C.; Coman, I.G.; Arion, F.H. Research on Innovative Business Plan. Smart Cattle Farming Using Artificial Intelligent Robotic Process Automation. Agriculture 2021, 11, 430 . https://doi.org/10.3390/ agriculture11050430

Academic Editors: Michele Mattetti and Luigi Alberti

Received: 13 April 2021

Accepted: 7 May 2021

Published: 10 May 2021

Publisher's Note: MDPI stays neutral with regard to jurisdictional claims in published maps and institutional affiliations.

Copyright: (c) 2021 by the authors. Licensee MDPI, Basel, Switzerland. This article is an open access article distributed under the terms and conditions of the Creative Commons Attribution (CC BY) license (https:/ / creativecommons.org/licenses/by/ $4.0 /)$.

\begin{abstract}
Integrating livestock management with the required devices and sensors is now seen as a critical factor in the agricultural sector's long-term success. The findings revealed that the agricultural business sector is open to implementing Information and Communication Technology (ICT) solutions, so the aim of this paper is to determine how advantageous it is for Romanian farmers to invest in a project that employs smart cattle farming methods that incorporate Artificial Intelligence (AI), Robotic Process Automation (RPA) and the Internet of Things (IOT). An unstructured interview was used to gather empirical evidence during a focus group meeting. Analyzing the selected primary performance metrics, it was projected that the farm's profitability would increase by 19 percent, productivity would increase by 21 percent, and the farm's environmental impact would decrease by 22 percent. Automation and remote work would help minimize the farm's worker burden while also making control panels, decision-making files, and data analysis more available. In order for the domain to be as prosperous as possible, farmers must be made aware of the benefits of using these emerging technologies for closing the gap between farmers and Information Technology (IT) solution providers, and this can be accomplished through continuous training for both farmers and their technology vendors.
\end{abstract}

Keywords: agriculture 4.0; farm automatization; agricultural digitalization; AI technologies; IOT

\section{Introduction}

One of the basic branches of agriculture is cattle farming [1] and it occupies a priority place in the economy of animal production [2] (p. 92). Cows are responsible for a variety of products that also derive from this from this important branch, such as: milk, meat, skins, manure, etc. [2] (p. 92). The economic situation of dairy farms in the European Union (EU) is unstable and strongly differentiated from one-member countries to another [2] (p. 92). According to Eurostat's statistics a total of 158.2 million tons of raw milk is produced in the EU, an increase of 1.4 million tons from year-to-year [3]. Of these, 143.1 million tons are cow's milk. Romania occupies the penultimate position in the EU for cow production, which reflects the inadequate structure of dairy farms. Farmers need to join associations to better manage agricultural inputs, increase yields and production, reduce costs, and sell raw milk efficiently [4].

This paper brings a new perspective on how the implementation of IT technologies and innovations in agriculture (animal husbandry) can improve the overall productivity of 
the industry in the field. It contributes to the existing specialized literature by proposing a new method (methodologies/business plan) that can be easily implemented by the business owners, with the help of a standardized procedure, customized and adapted to the specificities of a farm/business. Cattle breeding and exploitation is a traditional activity of the rural population and gives the character of a sustainable and promising activity [5], which must include a grazing plane for the habitat conservation purposes [6]. Beef is very important because it is a safe resource for trade, ensures labor stability, ensures domestic and export needs, which bring high incomes to producers [7] (pp. 75-96). Milk is a strategic product with a special impact on children, the elderly, and those with various diseases [8]. Due to its complex chemical composition, high biological value and high degree of digestibility, milk represents a product of high importance [9]. Cows produce more milk than their offspring require, and man has taken advantage of this since the dawn of time [7] (pp. 75-96). Breeding programs have successfully increased the amount and quality of milk cows produce. Cow's milk contains about $87.4 \%$ water and about $12.6 \%$ milk solids (total solids) the latter comprising about 3.9\% fat, 3.2\% protein, $4.6 \%$ lactose (anhydrous), and $0.9 \%$ 'other solids', i.e., minerals, vitamins, etc. [7] (pp. 75-96). Milk could be considered a complete food product for people with nutritional needs [10]. Milk is a crucial agricultural product for the EU, ensuring that the stability of agricultural production still has the greatest importance as it had when the foundation of European Community took place [8] (pp. 17-33). The average world milk consumption is estimated at $107 \mathrm{~L}$ per capital, which varies in $380 \mathrm{~L}$ in Europe, $280 \mathrm{~L}$ in North America, and $50 \mathrm{~L}$ in East Asia [11].

In general terms, usually the more intensive a farm is, the greater the revenue turnover, yet efficient farms are found in all sizes and categories, with many of the smaller farms experiencing relatively high technical efficiency [12] (pp. 219-240). The number of farms for milk production using any type of Automatic Milking System (AMS) is constantly growing, especially in Eastern Europe [13] (p. 2). In recent years, the number of AMS installed worldwide has increased dramatically and the worrying reality is the quality of milk produced and how it compares to conventional milk [14] (p. 1). Some research shows that the use of any kind of Conventional Milking System (CMS) is more cost-effective than the AMS [9] (p. 2). The biggest advantages of the AMS are the quality of the milk, the health and welfare of the animals, the large amount of milk, the reduction of the labor force and a better social life of the dairy producers [15] (pp. 3-14). For commercial farms, automatic milking saves time compared to manual milking [16].

Since the 1970s, there has been discussions of food security, a relatively recent concept. Food security, a component of economic security, requires food producers to have access to the agricultural resources available for this purpose, with costs that allow them to be produced sustainably so that they can be delivered to consumers at affordable prices. [17]. In the food industry, especially in the dairy industry, the concept of hazard analysis and critical control points (HACCP) guarantees the quality of food due to their entire chain of supervision, "from farm to fork" [18] (pp. 173-177).

Given that external threats lead to mass contamination, digitalization in the agri-food industry is becoming a necessity [19]. These digital technologies such as AI, large volumes of data, and robotics can help farmers and companies to provide safe food, streamline processes, and create new products and services. The benefits of using these digital technologies are known to farmers and may include animal performance, optimizing production factors, reducing labor, agricultural data flows, improving conditions for farmers and reducing the negative impact of agriculture on the environment [18].

Smart Farming (SF) refers to the application of ICT in agriculture. The use of these technologies for farming activities stand for innovation and examples of innovative technologies are sensors, robots, weather satellites, and so on [20]. These technologies rely on data and they are dependent of the internet. By collecting and analyzing these data, the efficiency of production processes increases, so that all actors involved, from farmers, companies, and institutions, are motivated to work together to use innovative technologies [19]. SF can be defined as a facilitator of efficient, productive, and profitable agricultural 
enterprises [21] (pp. 179-187). The development of data applications is a social product of the interactions between people, institutions, and technology itself. Basically, Big Data (BD) applications are intrinsically sociotechnical [22]. Currently, farmers considering adopting smart agriculture are faced with the absence of legal and regulatory frameworks around the collecting, sharing and use of agricultural data [23]. Farmers and firms are creating, adapting, and adopting a range of new hardware, software, mobile apps, sensor technologies, and $\mathrm{BD}$ applications, all involved in disrupting the established structures within the farm machinery and associated data sectors [24].

Similar results were observed during research carried on by the authors to observe the links and disparities among the agriculture and ICT sectors, with a study case in Romania, carried on in in frame of TRACK Project (COS-CLUSTPARTN-2017-3-02: "Tracking opportunities to develop and strengthen data collection and big data in agri-chain to increase competitivity of SMEs-TRACK". Project was co-funded by the European Union's COSME Programme). The main findings revealed that agricultural business sector is open for adopting ICT solutions, and they need solutions dedicated to their specificities of the farm or company. IT managers are facing complications in adopting appropriate ICT solutions for their business. A slow transition towards agri-food companies is observed. ICT companies must bridge the gap between innovation and farmers. There are some unique experiences that began on both sides: supply and demand, and this is the starting point of this article, from where the idea of this study came from. Consequently, the goal of the paper is to develop creative solutions to adapt the cow farm software model based on innovative field technology, which enables farm productivity to be increased while labor and time spent on the farm to be reduced.

The research question from which the substantiation of this article was based is as follows: "Is it opportune for Romania farmers to invest in a project that uses smart cattle farming methods integrating Artificial Intelligence (AI), Robotic Process Automation (RPA) and Internet of Things (IOT)?"

For finding the answer to this question, a number of secondary key questions were set up for our article:

How can innovative technologies on the market be integrated into the operational activity of farms and how will the farmer benefit from them?

Will the farm profitability be increased, and will there be an increase in production?

Will these technologies help the environment?

The research results will lead to the adoption of disruptive technologies in animals, RPA, Industrial Internet of Things (IIOT), in order to give efficiency, sustainability, and competitiveness to enterprises, as well as to increase confidence in disruptive technologies in Industry 4.0.

The first objective is to integrate the Livestock Management module with the required devices and sensors, cloud computing, RPA, and BD, while paving the road to full automation and changing the gates, scales, windows, climate systems, watering systems, feeding systems, and adding milking robots. The Livestock module is all about the wellbeing of the cattle, its movement, alimentation, medical treatment, sleeping and milking periods, and so on. This first objective specifically will generate many use cases.

\section{Materials and Methods}

\subsection{Business Models-Innovative Business Model}

Pisano [25] mentioned in 2015 that in the global framework that seems to affect companies as well as human conduct, new socioeconomic and technical patterns are emerging. High uncertainty caused by rapid technological innovation and global competition pushes organizations, in order to gain competitive advantages and grow their market share, to develop and use various business models [26] (pp. 7-17).

To understand which characteristics of a trend must be integrated in a new business is not an easy challenge, but it is strategically vital if entrepreneurs are to maintain inspiration to run new businesses [25]. 
The increasingly intense and volatile environment in which modern businesses must operate necessitates the use of creative solutions in various areas of business activity [27]. Because of today's tough economic conditions for business groups, implementing technologies only in product and process areas may be inadequate for achieving the enterprise's set goals [27]. Dynamic and tumultuous economic environments encourage industries to seek innovation in production, processes, and organizational areas of business operations. As a result, the need to make changes may affect the company [28] (pp. 352-364), whereas the need for change may lead to a new Business Model (BM) [29] (pp. 1023-1030).

\subsection{Focus Group}

Empirical data was collected in December 2020 at a one-day focus-group meeting. The focus group is a qualitative data collection method, similar to the interview, that is intended to use the group dynamics [30] (pp. 491-497). They are unstructured interviews that allow the participants and the researchers to create knowledge together rather than to focus on a singular solution to address the research question [31] (pp. 400-417). The group environment encourages the participants to engage in discussions and express ideas they had not thought of on an individual basis [31] (pp. 400-417). In recent years focus groups have become a popular research method in this field [32] (pp. 400-417).

The meeting consisted in two parts. Firstly, a group of 10 farmers was consulted in order to identify the most important problems they face and to discuss their solutions. In the second part the business model and the conclusions of the first session were presented to a group of 12 stakeholders and experts. The aim of the second session was to validate the model and the results, and also to identify additional solutions, opportunities, limitations, and barriers regarding the implementation of the model. Thus, the participants were selected based on their expertise in different key aspects [33] of the proposed model, as follows:

- Cluster (1; Agriculture) and farmers associations (2)-Farmers needs and market opportunities for the product;

- Clusters (3; IT, Environment and Green energy) - the model contribution to a low carbon and climate resilient economy in agriculture and food sectors;

- Business consultant (2)—business model and economic sustainability;

- IT providers (2) and Universities (2) - technical solutions;

Due to the SARS-CoV-2 virus pandemic constraints, the research was implemented online, through a video conference. This approach limits the interactions of the participants, but is less time consuming and expensive, and it is easier to record. The meeting was recorded and transcribed. This allowed for a greater familiarity with the data and also greater transparency [34].

\section{Results}

The solutions identified are new so far in the literature and are addressed mainly to companies in economically and technologically developed countries. The novelty brought by our article through the proposed solution consists in facilitating the diffusion of IoT at the level of developing countries, for small and medium enterprises (SMEs) in the agricultural field. The proposed new BM involves changing existing management systems with new ones, based on information technologies that ensure increased productivity of companies but also better management of environmental issues, while minimizing the negative impact of economic activities and maximizing biodiversity conservation.

\subsection{Essential Conditions for the Success of the Proposed Business Model}

While big sectors will likely invest with sophisticated facilities, data-free intuition management will no longer reflect the way professional farms work. In the long term, small farms will constantly adopt fundamental technologies. This should, particularly for the new generation of digital farmers, also be seen as a source of opportunities [34]. 
SMEs are progressively implementing simple technologies, while major farms are likely to invest in sophisticated equipment, so data-free intuition-based management for future business farms will no longer be the norm. The new generation of digitally knowledgeable young farmers should see this as a source of opportunities [34].

The proposed cattle farm robotic solution comes at a time when technological advancements have reached a favorable level of maturity and the implementation of such a mechanism has diminished costs [34]. There have been many good AI and IOT proof of concepts, most of them reaching the production environments. The available technologies are either open source or can be used as services [35], including a larger extent of provider independence; or they are available as standardized technologies from multiple vendors.

A competitive market in terms of service quality, low prices, and accurate cost estimates is assured by the large number of AI and IOT providers.

Collaborations are also a very important factor, for example, within clusters, technology adoption is simpler and quicker. In terms of maintaining economic sustainability and empowering entrepreneurs, disruptive innovations can be a solution. The implementation of technology for one of a cluster's members is sped up by proving it for the others as well, ensuring the never-ending demand of business competitiveness and empowerment.

Organic first actors are bound to have a more accelerated development if they choose to integrate Industry 4.0 technologies in their routine [36]. This model of farm should stand as a foundation of the digitalization mission; thus Agri-Food RPA has a serious growth potential in terms of market share.

IT and data gathering have achieved an unprecedented degree of confidence [37], while the afferent markets are in constant growth, in order to withhold the increased demands for state of the art/disruptive information technologies which are responsible as a result of smother and more accessible Agri-Food RPA services while keeping the costs competitive.

\subsection{Business Model}

\subsubsection{How the Organization Creates and Captures Value}

Centric IT, the organization responsible for developing the software, creates and captures revenue by a developed and currently operated Software as a Service (SAAS) portal which integrates complete business management modules. The goal is to further develop the capabilities with AI and IOT technology, transforming the expert software system to an intelligent software system. Farm hardware will be operated by cloud software robots, AI generated valuably will learn and evolve, learning how the human mind learns and interfering with prediction on the basis of our interpretation of the data that is being trained.

\subsubsection{The Target Audience}

Cattle farmers have been the main focus in the beginning, afterwards extending the services towards vegetable milk and meat processing businesses.

\subsubsection{The Key Differences}

The services are reaching the end user through a cloud portal which makes it more accessible and less costly to use the technologies. The modules function as an integrated environment, with data shared between (e.g., account and stock management work together). At the heart of the project are cognitive technology, cloud computing, and remote work.

The company offers a complete package for cloud computing services SAAS that include management, development, and business operations.

\subsubsection{Its Primary Capital and Partnerships}

Providing accessibility, availability, and data security are key factors, and there are established marketing, consulting, production, and support teams. A consortium of companies has been created, directly or indirectly interested in the field of agri-food, as an 
addition to our internal team. There is a well-established collaboration with farmers' groups that were the direct architects and beneficiaries of the first software module created by the company.

\subsubsection{Its Distribution Networks}

Given the fact that the platform is cloud based, the delivery channel mostly relies on the internet, through tools such as social media and online marketing, the participation in international events and fairs, symposiums, and conferences using the available Digital Innovation Hubs (DIH) communication channels is a must for the successful propagation of the project and a reliable BM.

\subsubsection{The Method by Which It Generates Revenue}

The company's clients benefit from the software's capabilities through a monthly or annual subscription. The price is calculated by the number of modules, the scale, and the number of users of each module used in the channel of the customer. This solution allows the beneficiary to upgrade or downgrade the package according to its needs. The AI technologies will be taxed as part of the monthly usage fee, while the IOT will be invoiced as an extra fee.

\subsubsection{Expenditure Framework}

The business model strategy is based on value and in the beginning the current customers would be the first to utilize this technology. It is foreseen that the initial number of customers will rise, in time, due to involvement in fairs, both domestically and globally, as well as the demonstration activities and showcases that will be hosted across Clusters and DIH.

According to financial forecasts for the next three years, the margin will show a 30 percent growth due to the emerging technology that the business is incorporating into its goods (modules), but the company's turnover will also increase by 200 percent, fueled by the number of agri-food consumers who will pick up enterprise's inventions alongside its partners.

\subsection{Description of Applied Technology}

The AI RPA with IOT for cattle farms in its core is driven by a business process automation designed to reduce the burden of repeated work. This technology will be incorporated with a variety of components, such as ICT, computers, hardware, and other robots, through the IIOT. RPA is sometimes correlated and referred to as software robotics, and figurative robots (bots) or AI "tour" the facility in order to achieve what this technology does best.

The IIOT's flexibility and adaptability makes it suitable for manufacturing, energy storage, integration of sensors, tools and technology relating to electronic industrial applications. This connectivity makes data gathering, distribution, and analysis simpler. The efficiency and ease of use benefits as an economic advantage. The IIOT consists of developing a distributed control system (DCS), which makes it possible to optimize and improve process controls by using cloud computing.

The main concept of this project is to have an AI information store, cognitive apps, linked inside a livestock farm to each sensor, computer, or robot. Communications must be allowed from sensors to BD to cognitive applications to computers and robots, for example (Figure 1).

A lot of hardware (e.g., picture and audio processing, air monitoring) has been integrated into and with the SAAS-RPA system from the 3rd partner, the Faculty's Research Centre. 


\subsubsection{Description of the Innovative Process Proposed by the Business Model}

The breakthrough is that RPA is responsible for both market and manufacturing processes within agri-food industries beginning with cattle farms in applications. The technology can help with animal protection, hygiene, and medical treatments such as antibiotics or other unsafe types of medical treatments. The system can help prevent the milk from a medicated cow to be mixed with the rest of the untreated cows. This type of system can help raise the quality of products, prevent contamination, and increase food security in a manner that man will never be able to without continuous surveillance.

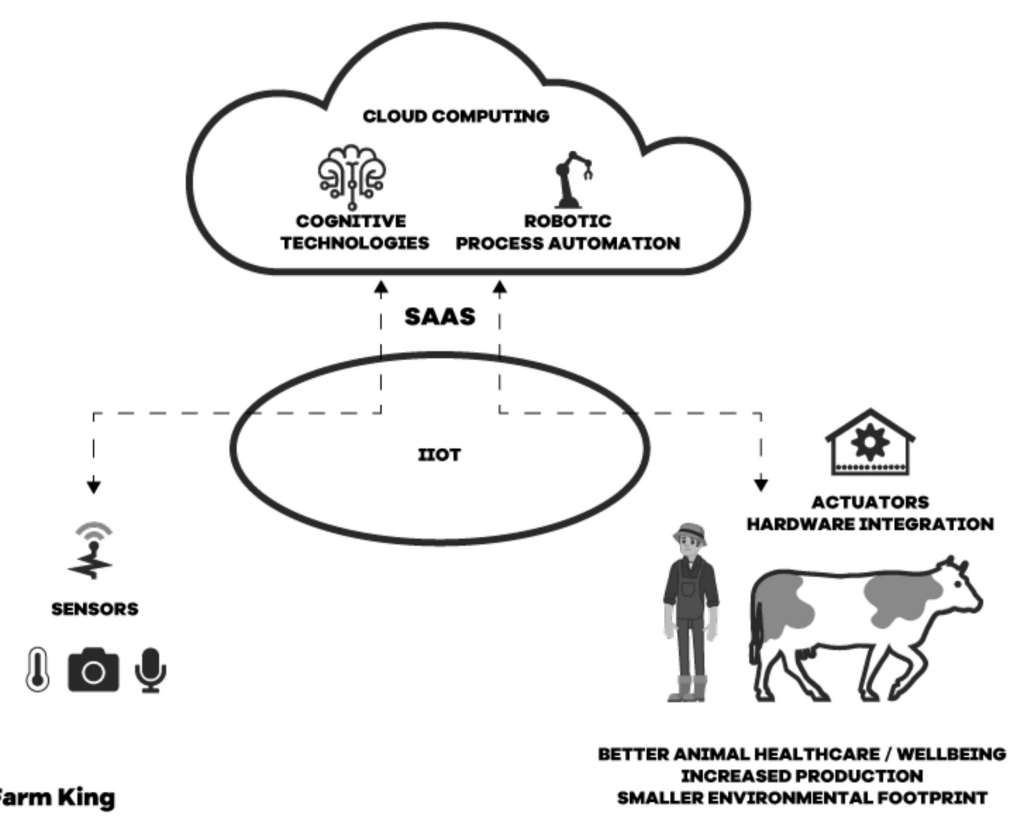

Figure 1. Industrial Internet of Thing connection diagram (realized by authors).

The framework uses SAAS, RPA, IIOT, Hardware, and Software Integration Tools to integrate/interoperate and will be sold as cloud-based services (Figure 2).

In virtual assisting and information dissemination environments the RPA systems have achieved good results, but with this research, RPA and IIOT can be experimented in the production processes.

\subsubsection{Interoperability}

As mentioned earlier, the technology also uses the internet and has a component infrastructure such that connectivity and interoperability with other applications, equipment, and robotics is central to it.

\subsubsection{Replicability}

Replication can be conveniently conducted as a SAAS gateway at the heart of the project. For faster international implementation and expansion, best practices and configuration data can be easily replicated. Integration hardware is still commonly used at the EU level by EU suppliers and cloud technology.

\subsubsection{Reuse}

The software center of the project has the design "Farm Software Ecosystem". In a typical environment, a knowledge base may often be used to enhance the efficiency of the cognitive program at a reduced cost. 


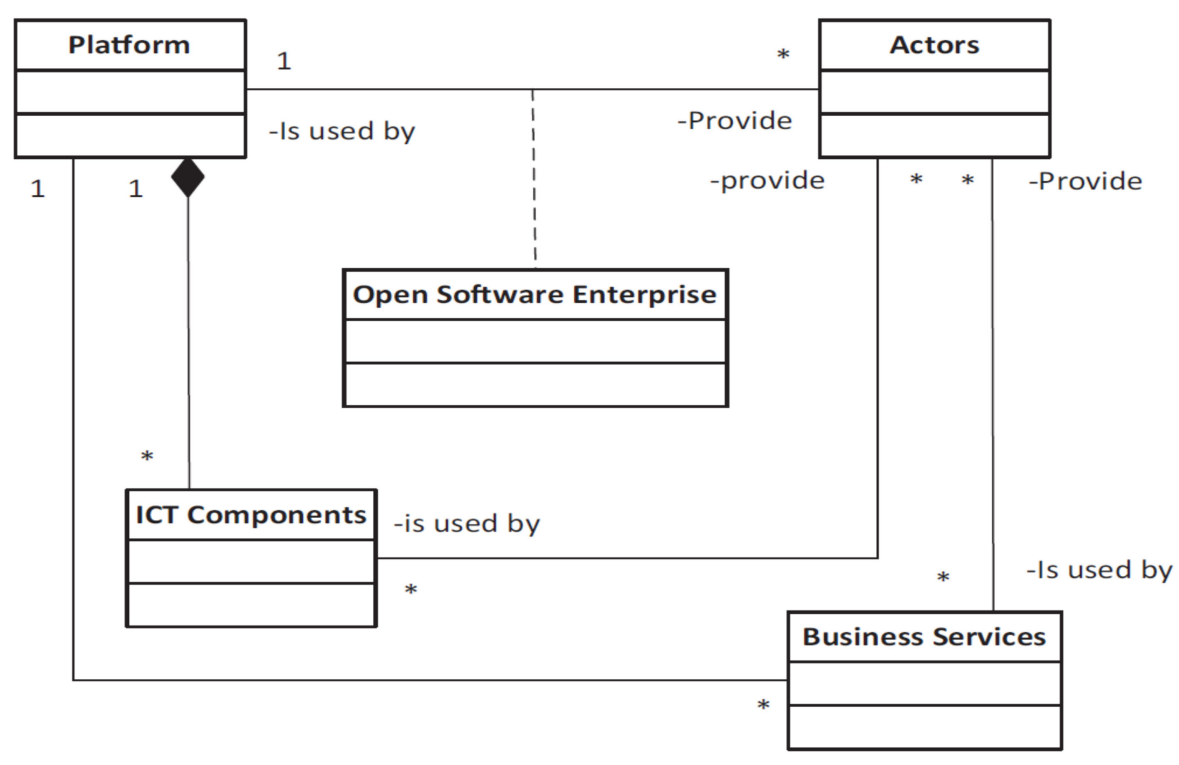

Figure 2. High level diagram of software architecture (reproduced from [38], with permission from Elsevier, 2021)

\subsection{Sustainability Impact}

The business model communicates the declared aim to achieve harmonious and sustainable growth for the agrarian sector through the goals and actions mentioned. Sustainability is a must and can be assured by:

1. Good practice in the operations carried out and changes made in the sector purchased along the way will be a good benefit and will continue through the coming years;

2. The multiplier and multi-function impact would contribute not only to benefits for consortiums on the labor market but for future generations who are best positioned to benefit from the advantages gained, savings made, and knowledge gained.

3. The establishment of reciprocal ties between members of the consortium, between the consortium and third companies that would enable access not only for the labor market, but also, indirectly, for the sharing of good experience. This will allow the acquisition of the requisite practical skills for possible business developments.

The consortium is structured to ensure that its findings are not a final objective but rather a starting point for prospective efforts which would generate more advantages:

1. To provide participants with cross-cutting business expertise and to assist them in creating new income.

2. The establishment of an advisory committee and its daily consultation would lead to a continuous database that will allow the participants and other stakeholders to access information (from the academic environment, socio-economic, or administrativelegislative environment).

3. Diagnostic and influence analysis are elements in which the key strategic directions for adaptation rely, but also the creation of new ones, and for the establishment (fundamental and/or applied) directives for research in the consortium, at cluster level, will be decided.

In order to strengthen creativity, collaboration with the corporate community, infrastructures, facilities, and technical expertise acquired during this time will be further used in university teaching at a proper level (Figure 3). The outcomes of smart cattle farming using AI and RPA's efforts can be institutionalized.

The findings are incorporated into the agri-food policy and plan at the state, regional, and national level. As previously discussed, the fact that market climate developments are a positive win and will continue in the next few years ensures longevity. 


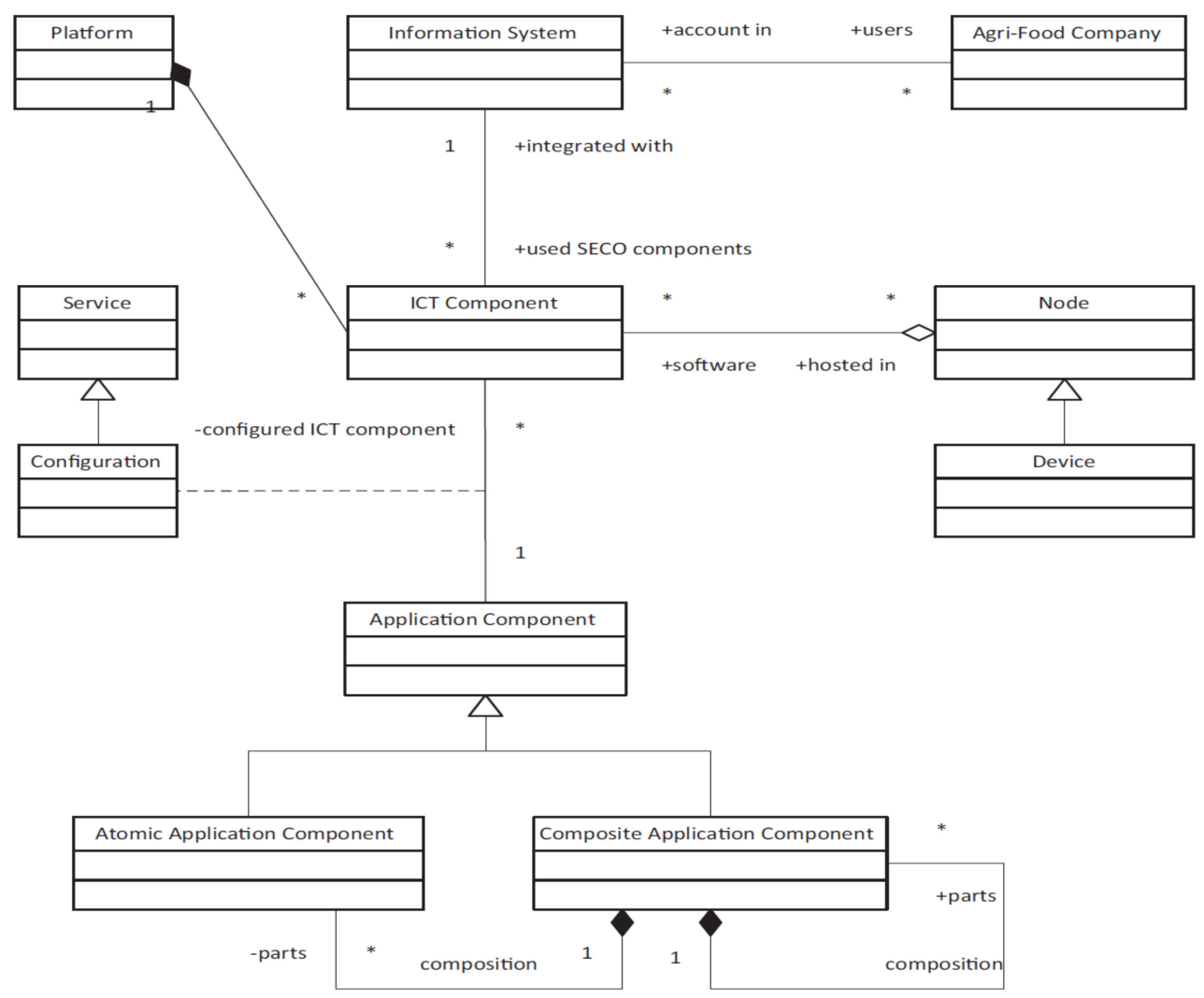

Figure 3. Components class diagram (reproduced from [38], with permission from Elsevier, 2021).

\subsection{Focus Group Estimations}

As an outcome of the implementation of the proposed solution, focus group estimated a number of Key Performance Indicators (KPIs) that could be evaluated during and after implementation. Therefore, 15 indicators were proposed and considered by the participants. Five indicators were supported by $83 \%$ (10 out of 12), and thus were selected as KPIs. To substantiate the decision, the KPI levels were estimated based on the average results of data collection and results analysis and comparisons after digitalization of farm activities/flows. The data has been gathered by the digitalization solutions usage and early adoption by 7 cattle farms with about 200 cattle and about 350 hectares of crops cultivated for animal food production, which represents a regular family farm in Romania.

- Reduction of human working hours at the farm, as an early estimation: in-office work by $82 \%$, total hours by $14 \%$. Of the whole farmer's activities more than $20 \%$ represents the office work (e.g., data fill-ins, reports generation, reports analysis, data-based decision making) and this can be optimized by $82 \%$ percent based on company's statistics. All participants supported this indicator. The biggest supporters were the Universities and the Agricultural Cluster. This answers one of the key issues raised by the 10 farmers in the first round of the focus group.

- Reduction of variable/hard-to-predict costs at the farm, as an early estimation: by at least $32 \%$, as result of digitalization for better management of resources, sensors monitoring and data archiving, pattern recognition of the cognitive technologies offers great premises in terms of costs reduction and costs estimation selected by 10 out of 12 participants. The providers of IT solutions, Cluster it, and business consultants were the promoters of the measure.

- Increase the profitability of the farm, as an early estimation: $19 \%$, by better resources management, better estimations, better data-based planning support, better yields out of disruptive industry 4.0 technologies adoption. It was proposed by all participants. It was also the main benefit identified by farmers. 
- Reduce the environmental impact, as an early estimation: $22 \%$, by better estimation together with better data-based decision-making generated smaller environmental footprints. Supported by 11 out of 12, especially by Environmental Clusters and Universities. They believe that: "Given the challenges we currently face; an innovative business model is bound to include an environmental dimension". In another quote one of the participants stated that "This dimension aligns the vision of the model with the EU environmental principles found and supported in the Common Agricultural Policy." However, the Farmers' Association was slightly retained, because in their opinion it can be "a limiting factor".

- Increase in production, as an early estimation: $21 \%$, for instance, in the cattle farm businesses the weather has a great impact on daily milk production for dairy farms but also in terms of daily weight gains for meat farms, so sensor based/weather forecast based decision-making digital systems offer a great support for production increase. The idea was supported by everyone, especially by farmers and business consultants.

According to a study done by Nesta in 2015, precision agriculture and investing in technological advancements in a farm can increase income possibilities by almost 20\% [39]. This increase in income can be achieved by cutting down costs with water or fertilizers, for example. Nesta mentions that "new agricultural technologies can drastically reduce the costs of fertilizers or increase yields by even 5\% [39]".

Sales are projected to increase slightly in the first year as a result of the teams' efforts to market the product, according to estimates. A small rise in turnover is anticipated in the first year as a result of efforts to promote the product in particular. The number of new customers is expected to rise significantly during the second and third year of implementation, as a result of the promotion carried out in the first year (Figure 4). The margin growth is due to the increase in revenue, and the cross-sales tactics. Customers get to know the brand and the company goods better and order new linked modules or other offerings on the same portal.

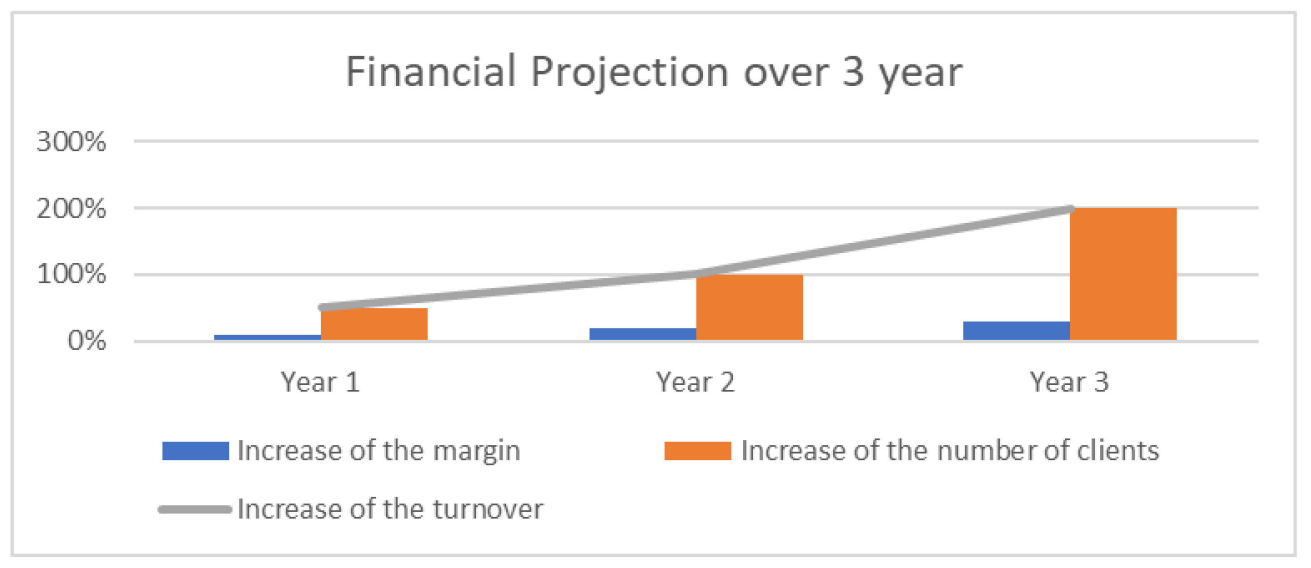

Figure 4. Financial projection over 3 years (authors' estimation).

\section{Discussion}

This paper aims to develop modern agriculture platforms and to increase the productivity of farms by rapidly integrating emerging digital innovations and innovative business models into agriculture.

Business model innovation (BMI) is one of the critical tasks that must be carried out on a continuous basis in every enterprise in order to maintain competitiveness in today's digital economy. Although interest in BM has grown substantially since the late 1990s, there are few known factors in BMI procedures in SMEs, which represent the vast majority of companies on the European market [40] (p. 344).

BMI is described as BMs' activity-based view leading to modifications at the BM of a company which are novel for the world or simply novel to the companies being 
analyzed [41] (pp. 216-226). The result of BMI is to reconfigure the existing BM activities of an enterprise new to the competing market [42] (pp. 183-198). It is a process which changes the core elements of a company and its business logic deliberately [43].

The digital and technological advancements realized through Industry 4.0 transformation are enhancing the quality of the product, working safety, forecasting faults and energy savings [44]. It is expected that in the next 5 years the production will be more efficient and trustworthy with up to $20 \%$ due to the Industry 4.0 approach $[45,46]$.

Many manufacturers are still involved in accelerating the adoption and integration of safe, reliable AI [47]. AI-based manufacturing in particular has the potential to enhance KPIs of the industry processes.

Gargiulo et al. [48] discussed in 2020 about the low adoption rate of AMS regardless of the increased possibility of productivity and profitability rates. Although his study results contest the research hypothesis, he concluded that CMS had similar results with the AMS in terms of human resource costs, income level and profitability. The initial investment and maintenance costs entail greater cost of AMS [48]. Bijl et al. discovered that the over-cost for AMS in the Netherlands were significantly lower [49] (pp. 239-248). New Zealand's expected results regarding AMS were much lower than the results of CMS, all this due to its fast depreciation rate, the high costs of maintenance and extensive reparation costs [50] (pp. 239-248). In Ireland, the medium-sized CMS farms, with an intermediate level of automation, showed that the revenues for AMS are much lower [51] (pp. 7700-7713).

There are also studies that have shown that automated systems can be more profitable than the conventional systems. In the United States it has been proven that AMS was most profitable for herd sizes between 120 and 240 cattle [52] (pp. 7739-7749).

The AMS technology is growing in importance in this field, and the estimates of the focus group participants take into account this trend. They argue that the proposed business model does not refer only to milking, but to the entire production flow. From animal welfare to the safety and quality of the product obtained. Thus, in addition to increased profitability, it also reduces the occurrence of certain risks and costs present in conventional systems.

In Romania, the future of agriculture is Emerging Media, and efforts to neglect it reign in the growth of this field. Farmers around the world use the IOT, robotics, AI, and comprehensive data to dramatically enhance the farming processes. For agro-industrial nations, scientific advancement in the new field study is seen as a solution. Agricultural technology focused on IT goods, automation, and robotics that are commonly used can catalyze the rise in efficiency and profitability of agricultural operations. Digital technology, according to research in the field, is a practical way to address existing challenges [53].

The digitization of agriculture increases the working conditions of farmers, decreases the detrimental environmental effects of agriculture, and also makes agricultural holdings much more profitable.

In the near future, digital farming becomes the conventional one, and manufacturers realize that they are able to obtain productive returns by investing in technologies, including saving seedlings, fertilizers, herbicides, pesticides and fuels [53].

The word "digital economy" is not described in any particular way. The economy is seen as a system for producing, exporting, trading, and exchanging products or services. A new economic framework may be called this as evolving technologies are used to develop, deliver, exchange, and consume processes. The major role of the global economy is on the consumer: the digital market is a place where goods and services are traded through an IT and software network. At the same time, the digital medium for assessing the operation patterns of market players is software, the hardware, and some operating regimes [54].

The project will help reduce the environmental footprint, using the most advanced technologies, the goal is to protect the environment and moderate the energy waste. The pollution should be close to non-existent in the first year of use. A specialized procedure for recycling, reuse, and transformation will be adopted, starting from the recycling of ordinary waste, streamlining processes, to the use of industrial composts which in addition to these are ecological and efficient method of recovery of organic waste of all kinds, as it 
is beneficial financially. Reducing emissions of air pollutants from many major sources, such as transport, industry, and electricity generation, will have a positive impact on the environment. Reducing air pollution helps combat climate change [55].

At the moment, both agricultural farms and ICT companies prosper for collaboration, but the profit is not distributed equally among the participants. The ICT are the ones that profit the most. Income from partnership will be shared by agri-food firms. Proposals include giving people access to $\mathrm{BD}$ and eliminating the need for labor. A core component of the new paradigm may be an online, interconnected value chain. There is plenty of space for additional measures in the agricultural sector's method of adjusting supply and technical demand.

\section{Limitations}

This business model, like others, is not immune to possible difficulties or challenges in the implementation process. The main complications that could disrupt the attempt to put into motion are:

1. There is a vast number of suppliers and lot of proprietary technologies;

2. Another issue can be represented by inadequate data sharing between ICT elements;

3. The drawbacks of software and hardware licenses;

4. Data access, data ownership and access control are another possible drawback;

5. The right to intellectual property;

6. Low acceptance and high consumption costs are in demand;

7. Short deployment times and a rapid learning curve or adoption of technological solutions;

8. Last but not least, the demand from the end consumer to slowly but gradually uptake the technology.

\section{Conclusions}

The most important benefits of the AMS are the increased milk consistency, animal health and welfare, the large amount of milk produced, and the reduction of labor needed. Farming dairy cows is a heavy physical labor that causes, in the long term, a series of conditions in the most experienced practicians of the job issues that can be solved with automation and remote work. Farmers need to be made aware of the advantages of using these emerging innovations. Issues related to the health of the animal can be found much faster with the help of RPA, resulting in a better medical assistance.

It is worth noting that, regardless of political changes, Romania's industrial transformation in the agri-food sector is important and should be embraced and implemented as a strategic priority in a multi-year strategy. Furthermore, digitalization in agriculture and the food industry should be seen as part of a larger digitalization phase. Romanian Government observed this necessity, so it specifically assumes, for the 2021-2027 strategy, that one of the major needs for achievement the Specific Objective 2 of the strategy (Strengthen market orientation and increase competitiveness), so-called Need 05. Increasing investment in precision agriculture and digitization is important, as they are essential tools for the sustainability of the agricultural sector and for increasing competitiveness [56].

Also, it observed that a close collaboration with transversal stakeholders is necessary. Correlating this need with the promising results of the research carried on by a heterogenous team, Romanian Government should focus on financing such consortium by allocating funds explicitly for agri-food sector needs in the selected European DIH in Digital Europe Program (E-DIH) from Romania to concentrate on the sector in each of the country's development regions, as part of the Digital Europe Program's phase. This is a supplementary step for establishing a central digital hub (platform) with the mission of integrating, organizing, and managing a collection of digital infrastructures (platforms, tools) at the regional and national levels, as well as a technology transfer center at the national level, representing and promoting technology transfer policies. Both are proposed in the National Strategic Plan (PNS) 2021-2027, which will manage the creation of common spaces between technology transfer centers and clusters (specific to the agri-food field). 
Author Contributions: Conceptualization, D.E.M., C.F. and F.H.A.; methodology, A.O. and R.F.D.; software, C.F.; validation, C.F. and F.H.A.; formal analysis, F.D., A.O. and I.G.C.; investigation, D.E.M., C.F. and F.H.A.; resources, F.H.A. and C.F.; data curation, F.D., A.O. and I.G.C.; writing-original draft preparation, D.E.M.; writing-review and editing, F.H.A.; visualization, C.F. and R.F.D.; supervision, F.H.A.; project administration, C.F.; funding acquisition, F.H.A. and C.F. All authors have read and agreed to the published version of the manuscript.

Funding: This research received no external funding.

Institutional Review Board Statement: Not applicable.

Informed Consent Statement: Not applicable.

Data Availability Statement: Not applicable.

Acknowledgments: A.F.H. acknowledge the support by AgroTransilvania Cluster, through the project TRACK Project (COS-CLUSTPARTN-2017-3-02: "Tracking opportunities to develop and strengthen data collection and big data in agri-chain to increase competitivity of SMEs-TRACK". Project was co-funded by the European Union's COSME Programme) and through the project "AgroTransilvania Cluster-Cluster specialized in bioeconomy" (Competitiveness Operational Program Axis 1. Program co-financed by the European Regional Development Fund "Investing for your future", Section B-Competition code POC-A1-A1.1.1-B-2015-Project type-Innovation clusters. P_35_476, co-funded by European Regional Development Fund).

Conflicts of Interest: The authors declare no conflict of interest.

\section{References}

1. Aleksic, S.; Pantelic, V.; Radovic, C. Livestock production: Present situation and future development directions in Republic of Serbia. Biotechnol. Anim. Husb. 2009, 25, 267-276. [CrossRef]

2. Poczta, W.; Średzińska, J.; Chenczke, M. Economic situation of dairy farms in identified clusters of European union countries. Agriculture 2020, 10, 92. [CrossRef]

3. Eurostat. Available online: https://ec.europa.eu/eurostat/statistics-explained/index.php/Milk_and_milk_product_statistics (accessed on 3 March 2021).

4. Popescu, A. Discrepancies in dairy farms structure between Romania and the EU-28 top countries raising cows in the period 2010-2017. In Annals of the Academy of Romanian Scientists Series Agriculture, Silviculture and Veterinary Medicine Sciences; Editura Academia Oamenilor de Știință din România: Bucharest, Romania, 2018; Volume 7. [CrossRef]

5. Escribano, A.J. Organic Livestock Farming: Challenges, Perspectives, and Strategies to Increase its Contribution to the Agrifood System's Sustainability-A Review. In Organic Farming-A Promising Way of Food Production, 1st ed.; Konvalina, P., Ed.; InTechOpen: London, UK, 2016; pp. 229-260. [CrossRef]

6. Perrino, E.V.; Musarella, C.M.; Magazzini, P. Management of grazing Italian river buffalo to preserve habitats defined by Directive 92/43/EEC in a protected wetland area on the Mediterranean coast: Palude Frattarolo, Apulia, Italy. Euro Mediterr. J. Environ. Integr. 2021, 6, 32. [CrossRef]

7. Harding, F. Milk Quality, 1st ed.; Springer: Boston, MA, USA; Blackie Academic \& Professional: New York, NY, USA, 1995; pp. 75-96.

8. Yılmaz, Ö.T. A study of milk support policies in the European Union and in Turkey. Eur. J. Interdiscip. Stud. 2017, 9, 17-33.

9. Mehta, B.M. Chemical Composition of Milk and Milk Products. In Handbook of Food Chemistry; Cheung, P., Mehta, B., Eds.; Springer: Berlin, Heidelberg, 2015. [CrossRef]

10. Banu, C. Manual of the Food Industry Engineer; Technical Publishing House: Bucharest, Romania, 2002; Volume I.

11. Stoicescu, A.V. Monitoring of Chemical Residues in Some Foods of Animal Origin. Ph.D. Thesis, Faculty of Veterinary Medicine, University of Agricultural Sciences and Veterinary Medicine of Bucharest, Bucharest, Romania, 2008.

12. Nehring, R.; Sauer, J.; Gillespie, J.; Hallahan, C. United States and European Union Dairy Farms: Where Is the Competitive Edge? Int. Food Agribus. Manag. Rev. 2016, 19, 219-240.

13. Matei, A.C.; Creangă, Ș.; Davisescu, M.A.; Doboș, B.I.; Porosnicu, I.; Mădescu, B.M. Research on the economic efficiency of farms in the function of the milking system. In Scientific Papers: Series D, Animal Science-The International Session of Scientific Communications of the Faculty of Animal Science; University of Agricultural Sciences and Veterinary Medicine of Bucharest: Bucharest, Romania, 2020; Volume 63.

14. Helgren, J.M.; Reinemann, D.J. Survey of milk quality on United States dairy farms utilizing automatic milking systems. In 2003 ASAE Annual Meeting; American Society of Agricultural and Biological Engineers: St. Joseph, MI, USA, $2003 ;$ p. 1.

15. Lind, O.; Ipema, A.H.; Koning, C.D.; Mottram, T.T.; Hermann, H.J. Automatic milking. Bull. Int. Dairy Fed. 2000, $348,3-14$.

16. Mishra, A.; Khatri, S.; Jha, S.; Ansari, S. Effects of Milking Methods on Milk Yield, Milk Flow Rate, and Milk Composition in Cow. Int. J. Sci. Res. Publ. 2020, 10, 9765. [CrossRef] 
17. Tobă, G.F.; Garlea, C.; Paraschivescu, M.T.; Sandu, M.; Strateanu, A.-G.; Ciornei, L.; Pipirigeanu, M.; Dobre, A.I.D. Strategie de Dezvoltare a Biodiversității Zootehnice și Agrosilvice După Criza de Coronavirus; Academia Română, Secția de Stiințe Economice, Juridice și Sociologie Centrul de studii și cercetări de biodiversitate agrosilvică „,acad. David Davidescu”: București, Romania, 2020.

18. Grădinaru, A.C.; Creangă, S..; Solcan, G. Milk-A review on its synthesis, composition, and quality assurance in dairy industry. Hum. Vet. Med. 2015, 7, 173-177.

19. Bacco, M.; Barsocchi, P.; Ferro, E.; Gotta, A.; Ruggeri, M. The digitisation of agriculture: A survey of research activities on smart farming. Array 2019, 3, 100009. [CrossRef]

20. Van der Burg, S.; Bogaardt, M.J.; Wolfert, S. Ethics of smart farming: Current questions and directions for responsible innovation towards the future. NJAS Wagening. J. Life Sci. 2019, 90, 100289. [CrossRef]

21. O'Grady, M.J.; O'Hare, G.M. Modelling the smart farm. Inf. Process. Agric. 2017, 4, 179-187. [CrossRef]

22. Jakku, E.; Taylor, B.; Fleming, A.; Mason, C.; Fielke, S.; Sounness, C.; Thorburn, P. "If they don't tell us what they do with it, why would we trust them?" Trust, transparency and benefit-sharing in Smart Farming. NJAS Wagening. J. Life Sci. 2019, 90, 100285. [CrossRef]

23. Wiseman, L.; Sanderson, J.; Zhang, A.; Jakku, E. Farmers and their data: An examination of farmers' reluctance to share their data through the lens of the laws impacting smart farming. NJAS Wagening. J. Life Sci. 2019, 90, 100301. [CrossRef]

24. Phillips, P.W.; Relf-Eckstein, J.A.; Jobe, G.; Wixted, B. Configuring the new digital landscape in western Canadian agriculture. NJAS Wagening. J. Life Sci. 2019, 90, 100295. [CrossRef]

25. Pisano, P.; Pironti, M.; Rieple, A. Identify Innovative Business Models: Can Innovative Business Models Enable Players to React to Ongoing or Unpredictable Trends? Entrep. Res. J. 2015, 5, 181-199. [CrossRef]

26. Bashir, M.; Verma, R. Why Business Model Innovation is the New Competitive Advantage. Iup J. Bus. Strategy 2017, 14, 7-17.

27. Chaston, I.; Scott, G.J. Entrepreneurship and open innovation in an emerging economy. Manag. Decis. 2012, 50, 1161-1177. [CrossRef]

28. DeTienne, D.R.; Koberg, C.S. The impact of environmental and organizational factors on discontinuous innovation within high-technology industries. IEEE Trans. Eng. Manag. 2002, 49, 352-364. [CrossRef]

29. Grabowska, M. Innovativeness in Business Models. Procedia Comput. Sci. 2015, 65, 1023-1030. [CrossRef]

30. Freeman, T. Best practice' in focus group research: Making sense of different views. J. Adv. Nurs. 2007, 56, 491-497. [CrossRef]

31. Rodriguez, K.L.; Schwartz, J.L.; Lahman, M.K.E.; Geist, M.R. Culturally responsive focus groups: Reframing the research experience to focus on participants. Int. J. Qual. Meth. 2011, 10, 400-417. [CrossRef]

32. Richard, A. Krueger and Mary Anne Casey. In Focus Group: A Practical Guide for Applied Research, 5th ed.; Sage Publishing: Thousand Oaks, CA, USA, 2015; ISBN 978-1-4833-6524-4.

33. Linneberg, M.S.; Korsgaard, S. Coding qualitative data: A synthesis guiding the novice. Qual. Res. J. 2019. [CrossRef]

34. Saiz-Rubio, V.; Rovira-Más, F. From Smart Farming towards Agriculture 5.0: A Review on Crop Data Management. Agronomy 2020, 10, 207. [CrossRef]

35. Lamnabhi-Lagarrigue, F.; Annaswamy, A.; Engell, S.; Isaksson, A.; Khargonekar, P.; Murray, R.M.; Nijmeijer, H.; Samad, T.; Tilbury, D.; Van den Hof, P. Systems \& Control for the future of humanity, research agenda: Current and future roles, impact and grand challenges. Annu. Rev. Control 2017, 43, 1-64.

36. Metzger, L. Milk composition testing: From dairy farmer payment to dairy processor efficiency to dairy farm and animal diagnostics. J. Dairy Sci. 2019, 102 (Suppl. 1), 5.

37. Zhang, Y.; Geng, P.; Sivaparthipan, C.B.; Muthu, B.A. Big data and artificial intelligence based early risk warning system of fire hazard for smart cities. Sustain. Energy Technol. Assess. 2021, 45, 100986. [CrossRef]

38. Kruize, J.W.; Wolfert, S.; Scholten, H.; Verdouw, C.; Kassahun, A.; Beulens, A. A reference architecture for Farm Software Ecosystems. Comput. Electron. Agric. 2016, 125, 12-28.

39. Nesta. Available online: https://www.nesta.org.uk/blog/precision-agriculture-almost-20-increase-in-income-possible-fromsmart-farming/ (accessed on 24 March 2021).

40. Pucihar, A.; Lenart, G.; Kljajić Borštnar, M.; Vidmar, D.; Marolt, M. Drivers and Outcomes of Business Model Innovation- Micro, Small and Medium-Sized Enterprises Perspective. Sustainability 2019, 11, 344. [CrossRef]

41. Zott, C.; Amit, R. Business model design: An activity system perspective. Long Range Plan. 2010, 43, 216-226. [CrossRef]

42. Bucherer, E.; Eisert, U.; Gassmann, O. Towards Systematic Business Model Innovation: Lessons from Product Innovation Management. Creat. Innov. Manag. 2012, 21, 183-198. [CrossRef]

43. Santos, J.; Spector, B.; Van der Heyden, L. Towards a theory of business model innovation within incumbent firms. In Business Model Innovation: The Organizational Dimension; Oxford University Press: Oxford, UK, 2015; p. 43.

44. El Hamdi, S.; Abouabdellah, A.; Oudani, M. Industry 4.0: Fundamentals and Main Challenges. In Proceedings of the International Colloquium on Logistics and Supply Chain Management (LOGISTIQUA), Paris, France, 12-14 June 2019.

45. Shrouf, F.; Ordieres, J.; Miragliotta, G. Smart factories in Industry 4.0: A review of the concept and of energy management approached in production based on the Internet of Things paradigm. In Proceedings of the IEEE International Conference on Industrial Engineering and Engineering Management, Bandar Sunway, Malaysia, 9-12 December 2014; pp. 697-701.

46. Wan, J.; Cai, H.; Zhou, K. Industrie 4.0: Enabling technologies. In Proceedings of the International Conference on Intelligent Computing and Internet of Things, Harbin, China, 17-18 January 2015; pp. 135-140.

47. European Cyber Security Organisation. Cyber Security for the Industry 4.0 and ICS Sector; European Cyber Security Organisation: Brussels, Belgium, 2018. 
48. Gargiulo, J.I.; Lyons, N.A.; Kempton, K.; Armstrong, D.A.; Garcia, S.C. Physical and economic comparison of pasture-based automatic and conventional milking systems. J. Dairy Sci. 2020, 103, 8231-8240. [CrossRef] [PubMed]

49. Bijl, R.; Kooistra, S.R.; Hogeveen, H. The profitability of automatic milking on Dutch dairy farms. J. Dairy Sci. 2007, 90, 239-248. [CrossRef]

50. Jago, J.G.; Davis, K.L.; Newman, M.; Woolford, M.W. An economic evaluation of automatic milking systems for New Zealand dairy farms. Proc. N. Z. Soc. Anim. Prod. 2006, 66, 263-269.

51. Shortall, J.; Shalloo, L.; Foley, C.; Sleator, R.D.; O'Brien, B. Investment appraisal of automatic milking and conventional milking technologies in A Pasture-based dairy system. J. Dairy Sci. 2016, 99, 7700-7713. [CrossRef]

52. Salfer, J.A.; Minegishi, K.; Lazarus, W.; Berning, E.; Endres, M.I. Finances and returns for robotic dairies. J. Dairy Sci. 2017, 100, 7739-7749. [CrossRef]

53. Nelli, A.-R. Perspectivele și problemele integrării în spațiul European al cercetării și educației. In Stiințe Economice, Revolution 4.0: Perspectives of The Development of Agricultural Entreprises in Digital Era; Universitatea de Stat "Alecu Russo" din Bălți: Bălti, Moldova, 2020; Volume VII.

54. Nelli, A.-R. Innovative development of the agri-food industry in the digital age. Akademos 2020. [CrossRef]

55. European Environment Agency. Available online: https://www.eea.europa.eu/ro/articles/un-aer-mai-curat-aduce (accessed on 11 April 2021).

56. Ministry of Agriculture and Rural Development. Needs Analysis of the National Strategic Plan (PNS) 2021-2027. 2020. Available online: https:/ /www.madr.ro/docs/dezvoltare-rurala/PAC_dupa_2020/2020/Analiza-nevoi-PNS-2021-2027.pdf (accessed on 11 April 2021). 